\title{
Research on the Construction of Campus Sports Competition Culture in Hubei Colleges and Universities
}

\author{
Tan $\mathrm{Wu}$ \\ Public Basic Course Department \\ Wuhan Technology and Business University \\ Wuhan, P.R.China
}

\begin{abstract}
Colleges and universities are the cradle of training talents, and good campus sports competition culture is one of the important indexes to mark the level of university. This paper takes the construction of campus sports competition culture in Universities in Hubei Province as the research object, and uses the methods of literature, questionnaire, expert interview, mathematical statistics and other research methods to explore the construction of campus sports competition culture in Colleges and universities of Hubei Province. The results find: (1) in the spiritual culture construction of campus sports competition of Colleges and universities of Hubei Province, sports knowledge culture, target culture and fashion culture need to be improved; (2) in the institutional culture construction of campus sports competition of Colleges and universities of Hubei Province, Campus sports civilized standards, Rules for athletes, Sports competition system, and Regulations on the safety control of sports activities need to be improved; (3) in the material culture construction of campus sports competition of Colleges and universities of Hubei Province, physical education teachers, sports publicity facilities and sports materials need to be improved.
\end{abstract}

Keywords-Hubei province; sports competition; culture construction

\section{INTRODUCTION}

Institutions of higher education are the bases for training qualified personnel, an important component of socialist construction, the future of the nation, and the hope of the nation, for they can cultivate qualified constructors and reliable successors of socialism with Chinese characteristics, with both ability and political integrity and all-round development. Campus culture is one of the important functions of leading the development of colleges and universities, and an important indicator of the level of the construction of colleges and universities, the trained college students with cultural temperament after graduation can influence others in society. Among them, the university

Fund project: Sponsored by the 2017 scientific \& technological research program of Educational Commission of Hubei Province: The Study on the Construction of Sport Competition Normalization Mechanism on the Campuses of Colleges and Universities in Hubei Province (Project number: B2017320). campus sports competition culture is a subsystem of the university culture. It is a form of culture that is completed by the teachers and students outside the sports curriculum and the sports class; it has its unique charm, and is presented by spiritual culture, institutional culture, material culture and so on. Therefore, research on the construction of campus sports competition culture in Colleges and universities will help to train high-quality talents for universities in Hubei province.

\section{RESEARCH OBJECTS AND METHODS}

\section{A. Research Objects}

A case study on construction of campus sports competition culture in colleges and universities of Hubei

\section{B. Research Methods}

1) Documentation method: In the study of the construction of campus sports competition culture in colleges and universities in Hubei province, this paper has searched papers, periodicals, papers and other papers from CNKI, Wanfang database and other search websites using such keywords as Colleges and universities in Hubei Province, sports competitions and cultural construction", and browsed at authoritative sports types, textbooks, and books, which has provided a lot of scientific theoretical basis for the research of the paper.

2) Questionnaire survey method: In the research process, two questionnaires for students and teachers of Research on the construction of campus sports competition culture in Hubei colleges and universities have been designed based on research content, and asked for correction from experts in the field many times, according to the experts' valuable opinions and suggestions, correction has been made to finally complete the questionnaire. The final version of the questionnaire was examined by the experts on its validity, the content validity and construct validity of the student questionnaire were 9 and 8.8 respectively, and the content validity and construct validity of the teacher questionnaire were 9.1 and 9 respectively. The reliability of the questionnaire was tested by repeated measures, and the two 
test interval was 4 weeks. Among them, the reliability of the students questionnaire was $94 \%$, and the reliability of the teachers questionnaire was $92 \%$.

According to the principle of random sampling, a questionnaire survey was conducted to students and teachers in 20 universities of Hubei Province, student questionnaires were distributed, an average of 150 copies per University, a total of 3000 copies, 2876 copies had been recovered, the recovery rate was $95.87 \%$, of the 2876 questionnaires recovered, 2705 were valid (1453 for boys, 1252 for girls), the effective rate was $90.17 \%$; and teacher questionnaires were issued, an average of 3 copies per University, a total of 60 copies, with 60 copies recovered, the recovery rate was $100 \%$, of the 60 questionnaires recovered, 57 were valid, with an effective rate of $95 \%$.

3) Expert interview method: In the course of the investigation, according to the content of the study, the experts of Hubei province were interviewed to know the current situation of the development of campus sports competition and the corresponding countermeasures of universities in Hubei Province in the form of seminars.

4) Mathematical statistics: In the course of the study, all the information collected by the questionnaire were analyzed and made statistics using Excel and SPSS software, some of the data were transformed into tables and charts for paper writing.

\section{RESULTS AND ANALYSIS}

\section{A. Understanding of Campus Sports Competition Culture in Colleges and Universities}

In view of construction of campus sports competition culture in universities and colleges in Hubei, form sports competition, spiritual culture, sports competition, system culture, sports competition, material culture and so on, some representative points have been selected for discussion and analysis through the questionnaire survey and the result are shown in "Table I", "Table II" and "Table III".

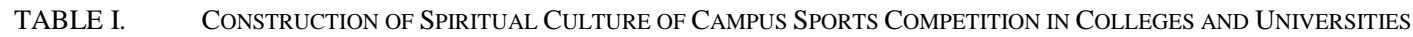

\begin{tabular}{|c|c|c|c|c|c|c|c|}
\hline \multirow{3}{*}{ Items } & \multirow{3}{*}{ Contents } & \multicolumn{6}{|c|}{ Results } \\
\hline & & \multicolumn{2}{|c|}{ Yes } & \multicolumn{2}{|c|}{ General } & \multicolumn{2}{|c|}{ No } \\
\hline & & $\mathbf{N}$ & $\%$ & $\mathbf{N}$ & $\%$ & $\mathbf{N}$ & $\%$ \\
\hline \multirow{3}{*}{ Sports morality culture } & Principle of fair competition & 2042 & 75.49 & 624 & 23.07 & 39 & 1.44 \\
\hline & Organizational discipline principle & 2214 & 81.85 & 464 & 17.15 & 27 & 1.00 \\
\hline & Collectivism principle & 2331 & 86.17 & 195 & 7.21 & 179 & 6.62 \\
\hline \multirow{3}{*}{ Sports knowledge culture } & Healthy body knowledge & 1857 & 68.65 & 764 & 28.24 & 84 & 3.11 \\
\hline & Knowledge of sports skills & 1078 & 39.85 & 1324 & 48.95 & 303 & 11.20 \\
\hline & Social physiological and psychological knowledge & 1367 & 50.54 & 989 & 36.56 & 349 & 12.90 \\
\hline \multirow{3}{*}{ Sports spiritual culture } & Combatant spirit & 2435 & 90.02 & 254 & 9.39 & 16 & 0.59 \\
\hline & Team spirit & 2534 & 93.68 & 165 & 6.10 & 6 & 0.22 \\
\hline & Law-abiding spirit & 2235 & 82.62 & 456 & 16.86 & 14 & 0.52 \\
\hline \multirow{3}{*}{ Sports concept culture } & Vent one's emotions & 2543 & 94.01 & 159 & 5.88 & 3 & 0.11 \\
\hline & Promote health & 2612 & 96.56 & 88 & 3.25 & 5 & 0.18 \\
\hline & Enrich life & 2134 & 78.89 & 269 & 9.94 & 302 & 11.16 \\
\hline \multirow{2}{*}{ Sports target culture } & Nearly and long term planning of School Physical Education & 886 & 32.75 & 954 & 35.27 & 865 & 31.98 \\
\hline & School physical education planning executive ability & 454 & 16.78 & 1687 & 62.37 & 564 & 20.85 \\
\hline \multirow[t]{2}{*}{ Sports custom culture } & Sports programs & 746 & 27.58 & 1624 & 60.04 & 335 & 12.38 \\
\hline & Sports periodicals & 447 & 16.52 & 1467 & 54.23 & 791 & 29.24 \\
\hline
\end{tabular}

TABLE II. CONSTRUCTION OF INSTITUTIONAL CULTURE OF CAMPUS SPORTS COMPETITION IN COLLEGES AND UNIVERSITIES

\begin{tabular}{|c|c|c|c|c|c|c|}
\hline \multirow{3}{*}{ Contents } & \multicolumn{6}{|c|}{ Results } \\
\hline & \multicolumn{2}{|c|}{ Yes } & \multicolumn{2}{|c|}{ Unknown } & \multicolumn{2}{|c|}{ No } \\
\hline & $\mathbf{N}$ & $\%$ & $\mathbf{N}$ & $\%$ & $\mathbf{N}$ & $\%$ \\
\hline Rules and regulations of school physical education & 16 & 80 & 3 & 15 & 1 & 5 \\
\hline Fitness guide for college students & 15 & 75 & 4 & 20 & 1 & 5 \\
\hline Code of practice for physical education teachers & 20 & 100 & 0 & 0 & 0 & 0 \\
\hline Sports classroom standard systems & 18 & 90 & 2 & 10 & 0 & 0 \\
\hline PE teacher rewards and punishments systems & 16 & 80 & 3 & 15 & 1 & 5 \\
\hline Comprehensive evaluation systems of students physical fitness & 19 & 95 & 1 & 5 & 0 & 0 \\
\hline Regulations for the administration of field device and equipment & 15 & 75 & 4 & 20 & 1 & 5 \\
\hline Rules for athletes & 5 & 25 & 8 & 40 & 7 & 35 \\
\hline Sports competition system & 12 & 60 & 5 & 25 & 3 & 15 \\
\hline Campus sports civilized standards & 8 & 40 & 9 & 45 & 3 & 15 \\
\hline Organization of sports management & 15 & 75 & 4 & 20 & 1 & 5 \\
\hline Regulations on the safety control of sports activities & 11 & 55 & 5 & 25 & 4 & 20 \\
\hline
\end{tabular}


TABLE III. CONSTRUCTION OF MATERIAl CULTURE OF CAMPUS SPORTS COMPETITION IN COLLEGES AND UNIVERSITIES

\begin{tabular}{|c|c|c|c|c|c|c|}
\hline \multirow{2}{*}{ Contents } & \multicolumn{6}{|c|}{ Results } \\
\cline { 2 - 7 } & \multicolumn{2}{|c|}{ Satisfied } & \multicolumn{2}{|c|}{ General } & \multicolumn{2}{c|}{ Dissatisfied } \\
\cline { 2 - 7 } & $\mathbf{N}$ & $\%$ & $\mathbf{N}$ & $\%$ & $\mathrm{~N}$ & $\%$ \\
\hline $\begin{array}{c}\text { Sports site } \\
\text { facilities }\end{array}$ & 1879 & $\begin{array}{l}69.4 \\
6\end{array}$ & 525 & 19.41 & 301 & 11.13 \\
\hline $\begin{array}{c}\text { Sports publicity } \\
\text { facilities }\end{array}$ & 1032 & $\begin{array}{l}38.1 \\
5\end{array}$ & 1112 & 41.11 & 561 & 20.74 \\
\hline $\begin{array}{c}\text { PE teaching } \\
\text { environment }\end{array}$ & 1637 & $\begin{array}{l}60.5 \\
2\end{array}$ & 659 & 24.36 & 409 & 15.12 \\
\hline $\begin{array}{c}\text { Sports } \\
\text { information }\end{array}$ & 618 & $\begin{array}{l}22.8 \\
5\end{array}$ & 723 & 26.73 & 1364 & 50.43 \\
\hline $\begin{array}{c}\text { Sports } \\
\text { competition fund }\end{array}$ & 1568 & $\begin{array}{l}57.9 \\
7\end{array}$ & 579 & 21.40 & 558 & 20.63 \\
\hline $\begin{array}{c}\text { Physical } \\
\text { education } \\
\text { teachers }\end{array}$ & 861 & $\begin{array}{l}31.8 \\
3\end{array}$ & 1002 & 37.04 & 842 & 31.13 \\
\hline $\begin{array}{c}\text { Construction of } \\
\text { sports clubs and } \\
\text { associations }\end{array}$ & 1765 & $\begin{array}{l}65.2 \\
5\end{array}$ & 521 & 19.26 & 419 & 15.49 \\
\hline
\end{tabular}

B. Spiritual Culture Construction of Campus Sports Competition of Colleges and Universities in Hubei Province

The campus sports spiritual culture is the embodiment of college students' participation in sports competition, also the core content of campus sports competition, it moreover decides the development direction of a campus sports competition, and reflects the value orientation and ideals and beliefs of campus sports competition. Good campus sports competition culture has condensed the distance between teachers and students in the campus, and showed the culture of sports competitions in aspects of sports ethics, sports knowledge, sports spirit, sports idea, sports target and sports fashion. Therefore, it is of great importance to build a competitive spirit culture in colleges and universities.

1) Ethical culture construction of campus sports competition of colleges and universities in Hubei province: Nowadays, moral crisis is more challenging than ever before, especially when college students are involved in sports competitions, sports ethics is one of the most important parts of the overall quality of college students, and the display of sports intrinsic value by college students. In the course of the study, a survey of the sports moral situation of college students participating in campus sports competitions in Hubei Province was made, it was found that college students in Hubei participation in campus sports competitions had a strong sense of identity on fair play $(75.49 \%$ identity), organizational discipline $(81.95 \%$ identity), collectivism (86.17\% identity) from dimensions of fair competition, organizational discipline, collectivism, sense of responsibility and utilitarian color.

2) Sports knowledge culture construction of campus sports competition of colleges and universities in Hubei province: There are many motivations for college students to engage in sports competitions, participants should have the most basic skills, that is, sports knowledge, and the degree of college Students' mastery of sports knowledge reflects the current situation of campus sports competition culture in colleges and universities. Therefore, in college students, we should popularize sports knowledge; broaden the scope of sports knowledge, so that more students can be more fully familiar with sports knowledge. Through a questionnaire survey, it was found that $68.65 \%$ of college students took part in physical education to recognize their health, and $50.54 \%$ of college students participated in sports competitions to promote social, physiological and psychological changes, while only $39.85 \%$ of college students knew how to use sports skills, $48.95 \%$ of the students knew certain knowledge of sports skills, and even $11.2 \%$ of college students did not know the knowledge of motor skills.

3) Sports spirit culture construction of colleges and universities in Hubei province: Campus sports spirit is the soul embodiment of university students participating in competition, it is gradually extracted by colleges and universities in the development of campus culture under certain social history and different environment, and it can reflect the common ideals and beliefs of campus teachers and students participating in sports competitions. By investigating the situation of sports spirit in colleges and universities in Hubei Province, it was found that $90.02 \%$ of students agreed to have the spirit of fighting to participate in sports competition, $93.68 \%$ of college students agreed to have cooperative spirit to participate in sports competitions, and $82.62 \%$ of college students believed that participation in sports competitions can embody the spirit of observing discipline and obeying the law.

4) Sports concept culture construction of colleges and universities in Hubei province: The concept of sports is the value orientation showed from fitness, recreation, body and mind, beauty when people participate in sport competition, good sports concept can promote people to participate in sports competitions, which plays a guiding role. When investigating the sports concept of college students in Hubei Province, it was found that $94.01 \%$ of college students believed participating in sports competitions can effectively vent displeasure, the vast majority $(96.56 \%)$ of college students believed that participating in physical education can promote health, and $78.89 \%$ of college students agree that participating in sports competitions can enrich life.

5) Sports target culture construction of colleges and universities in Hubei province: Sports goals are the expected results of participants wanting to achieve when participating in sports competitions, and also the degree of effort and direction of effort reflected from the process of participating in physical activities by participants. Clear sports goals can effectively promote participants to use a variety of ways to work hard, cooperate, or unite, to stimulate the potential of the participants and eventually enjoy the sports. When investigating the sports objectives of colleges and universities in Hubei, it was found that $35.27 \%$ of college students had a vague understanding of school 
sports development planning, even $31.98 \%$ of college students were not able to make clear long-term plans for school physical education; while in the school sports planning execution, $62.37 \%$ of college students were vague, even $20.85 \%$ of college students were not able to recognize the executive power of school physical education programs.

6) Sportsmanship culture construction of colleges and universities in Hubei province: Sportsmanship is the ethos and habit of sports competition in the popular society, therefore, if the campus is full of active sports habits, it can virtually promote college students to participate in sports, and make the campus full of youth and vitality. When investigating the sportsmanship situation of colleges and universities in Hubei, it was found that $57.97 \%$ of college students were hesitant consciously participating in sports competitions, $60.04 \%$ of college students hesitated to choose to watch sports programs, and $54.23 \%$ of college students were hesitant in knowing sports information via sport periodicals, and even $29.24 \%$ of college students refused to choose sports publications to recognize sports competitions.

\section{Sports Competition Systematic Culture Construction of Colleges and Universities in Hubei Province}

As the saying goes, "nothing will be executed well with any rules System culture is a standard system gradually established in the development of human society, the campus sports competition system culture is the regulatory framework regulated from aspects of college students sports teaching management, campus sports competition and the management of campus sports associations by colleges and universities according to the characteristics of selfdevelopment. The establishment of these rules and regulations is a comprehensive maintenance guarantee for the normal operation of the campus sports order; it also reflects the orientation of school leaders and PE teachers on the outlook on life, world outlook and values of college sports competitions, and also the foundation to promote the all-round development of campus culture.

The survey showed that colleges and universities in Hubei province held annual university sports meet, various sports cultural festivals, sports competitions and sports knowledge lectures, in this kind of sports culture atmosphere, system culture is the decisive factor. When investigating the rules and regulations establishment of Regulations on sports work, Fitness guide for College Students, Code of practice for physical education teachers, Sports classroom standard system, PE teacher rewards and punishments system, Comprehensive evaluation system of students physical fitness, Regulations for the administration of field device and equipment, Rules for athletes, Sports competition system, Campus sports civilized standards, Organization of Sports Management, Regulations on the safety control of sports activities in 20 colleges and universities in Hubei, it was found that 20 colleges and universities had established the Code of practice for physical education teachers, the teachers work in accordance with the codes; 19 colleges and Universities had established Comprehensive evaluation system of students physical fitness, students' comprehensive quality was evaluated according to the rules; 18 colleges and universities had established Sports classroom standard system, and emphasized the relevant classroom regulations in the first class of each semester; and 16 colleges and universities had established Regulations on sports work, PE teacher rewards and punishments system; 15 colleges and universities had established Regulations for the administration of field device and equipment, Organization of Sports Management, and Fitness guide for College Students, it showed that colleges and universities leaders attached importance to the development of sports culture; while there existed deficiency in construction of Sports competition system and Regulations on the safety control of sports activities, even less than half of colleges and universities set up relevant rules and regulations on Campus sports civilized standards; however, only 5 colleges and universities had established Rules for athletes, this was related to whether there are professional athletes in colleges and universities.

1) Construction of rules and regulations of school physical education: Among the formulated sports related legal documents in China, the most basic legal document is the rules and regulations of school physical education, which was approved by the State Council in February 1990, subsequently; the National Education Commission and the State Sports Commission jointly issued a notice on the implementation of the document. The Ordinance provides a general overview of sports work, including the teaching of physical education and extracurricular sports activities, after class sports training and competition, physical education teachers, fields, equipment, equipment and funds, organization and management, reward and punishment. The Ordinance covers sports related competitions in universities and schools, aiming at ensure that schools carry out smoothly sports related activities, and promote students to be excellent healthy. Through investigation, among 20 colleges and universities in Hubei Province, 17 colleges and universities were more aware of the regulations, while only 3 colleges and universities were vague about the regulations.

2) Construction of Fitness guide for college students: In higher education of 21 st century, in addition to the study of professional knowledge, we should pay attention to physical education to cultivate students' strong physique and healthy state of mind, and finally make them become qualified socialist successors. The Fitness guide for College Students is guided by "people oriented, Health first", it consists of two parts: theory and application, the theoretical part focuses on the concept of health, how to recover health, scientific exercise, fitness and nutrition, sports injury, and healthy lifestyle, while the application part focuses on application of a sports event. Through investigation, among 20 colleges and universities in Hubei Province, 15 colleges and universities were clear about the regulations, and 4 colleges and universities were vague about the regulations, while 1 did not even know these regulations. 


\section{3) Construction of code of practice for physical education teachers}

Sports related work in campus is the most important part in the work of the school, among them, the effect of sports work can directly affect the physical and mental health of students, students' learning, students' comprehensive quality and so on, therefore, only the strong and standard physical education teachers can promote students to learn sports better. Through investigation, all 20 colleges and universities in Hubei Province had this regulations, and it more importantly reveals the importance of the code, only regulate oneself first can we regulate others.

4) Construction of sports classroom standard system: The standard system of university sports class must follow the requirements in Sports classroom standard system, this system emphasizes the points of attention in PE Teaching, including requirements on clothing, diet, jewelry and so on out of class, and the observance of classroom discipline, safety education, etc., the system pays attention to specific issues of different sports curriculum objects, which can effectively prevent the occurrence of risks. Through investigation, among 20 colleges and universities in Hubei Province, 18 colleges and universities were quite clear about the system, and 2 were vague about the regulations, while still 2 did not even clearly know it.

5) Construction of PE teacher rewards and punishments system: PE teacher rewards and punishments system is also a motive force to promote teachers in physical education, and to promote the innovative teaching of physical education teachers, so that students can learn from sports and master something. Through investigation, among 20 colleges and universities in Hubei Province, 16 colleges and universities were quite clear about the system, and 3 were vague about the regulations, while still 1 did not even clearly know it.

6) Construction of comprehensive evaluation system of students' physical fitness: Comprehensive evaluation system of students physical fitness is the most direct and effective way to fully understand the basic situation of students, when physical education teachers are in the understanding of the basic situation of students, it can provide scientific basis for teachers in teaching physical education, this system is mostly based on the implementation of National standard of physical fitness for students. Through investigation, among 20 colleges and universities in Hubei Province, 19 colleges and universities were quite clear about the system; only 1 was vague about the regulations.

7) Construction of regulations for the administration of field device and equipment: The appearance of Construction of Regulations for the administration of field device and equipment has provided enough space for physical education, sports competition, allowed participants to orderly participate in exercise, let more people to enjoy public resources to achieve full fitness effect. Through investigation, among 20 colleges and universities in Hubei Province, 15 colleges and universities were quite clear about the system, and 4 were vague about the regulations, while still 1 did not even clearly know it.

8) Construction of rules for athletes: Rules for athletes is relevant regulations on professional athletes, through investigation, among 20 colleges and universities in Hubei Province, 5 colleges and universities were quite clear about the system, and 8 were vague about the regulations, while still 7 did not even clearly know it. It's also different in each campus, and most colleges don't have professional athletes, some sports colleges or comprehensive sports college have professional athletes, meanwhile, Construction of Rules for athletes shall be matched to implement to regulate competition behaviors to get good achievements, and to be recognized by the broad masses of the people.

9) Construction of sports competition system: The management on sports competition in China is unified, National Sports Commission provides protection for all kinds of sports events by formulating Sports competition system. Through investigation, among 20 colleges and universities in Hubei Province, 15 colleges and universities were quite clear about the system, and 5 were vague about the regulations, while still 3 did not even clearly know it.

10) Construction of campus sports civilized standard: The university campus is harmonious, each school staff should have a high level of self-cultivation and moral civilization, including daily behavior civilization, classroom civilization, language civilization, image civilization, sports field civilization and examination civilization, etc.. Through investigation, among 20 colleges and universities in Hubei Province, 8 colleges and universities were quite clear about the system, and 9 were vague about the regulations, while still 3 did not even clearly know it. Therefore, the emphasis should be preferentially laid on strengthening the sports civilization in the campus.

11) Construction of organization of Sports Management: Organization of Sports Management is a guarantee for the smooth going of a match; if there is organizational guarantee from preparation period to the continuous period, and the ongoing period to post period, it is a common source of strength between participants and staff. Through investigation, among 20 colleges and universities in Hubei Province, 15 colleges and universities were quite clear about the system, and 4 were vague about the regulations, while still 1 did not even clearly know it.

12) Construction of regulations on the safety control of sports activities: Safety in life is the premise of doing anything, if there is no safety, there will be danger. Then, when danger happens, it will affect many aspects of development. Therefore, Regulations on the safety control of sports activities is also the most effective regulation to promote school teachers and students to participate in campus sports competitions. Through investigation, among 20 colleges and universities in Hubei Province, 11 colleges 
and universities were quite clear about the system, and 5 were vague about the regulations, while still 4 did not even clearly know it. Therefore, we must strengthen safety education and create a safe sports competition environment.

\section{Sports Competition Material Culture Construction of Colleges and Universities in Hubei Province}

Sports competition material culture construction of colleges and universities is the most important medium for college students to participate in sports competitions, the level of material culture reflects the extent of campus sports culture in colleges and universities on one hand, while on the other hand, material culture also influences college students' participation in sports competitions and competition levels, material culture reflects the wisdom of the people through the cultural background of the site, sculpture and architecture to reflect people's wisdom, edify people's sentiment, therefore, the construction of the material culture of university sports competition shall be guaranteed in the material objective aspects to build a good material culture of campus sports competition and promote more participation by teachers and students in sports competitions.

1) Sports site facilities: With the continuous development of social economy, a large number of colleges and universities have built all kinds of stadiums and gymnasiums on campus. In addition to physical education, some PE education also bears multiple functions, for example, Gymnasium of Huazhong University of Science and Technology holds all kinds of large-scale activities every year, this also shows the important position of stadiums and gymnasiums in the development of university material culture; when investigating the satisfaction of sports facilities in 20 universities in Hubei Province, it was found that $69.46 \%$ of college students were satisfied with their school sports facilities.

2) Sports publicity facilities: Campus sports publicity facilities not only make the campus teachers and students to understand campus sports facilities, and choose to participate in sports competitions, and even stimulate sports lovers outside campus to join together in sports competitions. Investigation found that sports publicity facilities were poor in 20 colleges and universities in Hubei, $38.15 \%$ of college students were satisfied with the campus sports publicity facilities, and up to $41.11 \%$ of college students were not aware of the campus sports publicity facilities.

3) PE teaching environment: Good sports teaching environment is undoubtedly the most favorable guarantee to promote physical education, and even, it can imperceptibly promote the psychological touch and environmental impact behavior of students to participate in sports competitions. According to the survey, $60.52 \%$ of college students were satisfied with the campus sports teaching environment, and there were still $15.12 \%$ of college students dissatisfied with the campus sports teaching environment.
4) Sports information: Sports teaching materials, audiovisual materials, sports periodicals and other materials are the most scientific theoretical guidance for teachers and students to participate in sports competitions. Through investigation, it was found that 20 colleges and universities in Hubei province failed to prepare enough for sports materials, $50.43 \%$ of college students were dissatisfied with the status of sports materials, and only $22.85 \%$ of college students were satisfied with the status of sports materials.

5) Sports competition funds: Sports competition fund refers to the most powerful motive force to promote campus sports competitions and students' participation in sports competitions in addition to venues and facilities, sufficient funds can improve stadiums and sports facilities, therefore, the sufficient situation of sports competition funds is also one of the factors that affect the development of campus sports competitions. According to the survey, 57.97\% of college students were satisfied with the situation of school sports competition funds, and $20.63 \%$ of college students were still dissatisfied with the situation of College Students' sports competition funds.

6) Physical education teacher staff: College sports teachers play the role of engineers in construction of campus sports competition culture, on the one hand, students learn knowledge of sports competition through physical education teachers, on the other hand, physical education teachers are authoritative to the development of school sports competitions. However, through the investigation, it was found that the faculty of 20 colleges and universities in Hubei was a fly in the ointment, $31.83 \%$ of college students were satisfied with the school physical education teachers staff, while $31.13 \%$ of the college students were dissatisfied with the school physical education teachers staff.

7) Construction of sports clubs and associations: There are many forms of sports competitions in colleges and universities. Besides sports teaching and extracurricular activities, sports clubs or some sports associations will promote the development of campus sports competitions. Through investigation, it was found that some colleges had set up sports clubs for mass participation, every university had sports related organizations, and the development of sports clubs and associations had promoted the development of sports events at all circles and above the provincial level. A group of college students who had the potential for sports had been mined out through sports clubs or associations.

\section{CONCLUSION}

In the construction of spiritual culture of campus sports competition of colleges and universities in Hubei Province, sports knowledge culture, target culture and vogue culture need to be improved;

In the construction of constitutional culture of campus sports competition of colleges and universities in Hubei Province, Campus sports civilized standards, Rules for 
athletes, Sports competition systems and Regulations on the safety control of sports activities need to be improved.

In the construction of material culture of campus sports competition of colleges and universities in Hubei Province, physical education teachers, sports publicity facilities and sports materials need to be improved.

\section{REFERENCES}

[1] Zhang C Y, Zhong M B, and Wang Y Z. Research on fair competition and system construction of sports competition[J]. China Sports Science and Technology. 2007,43(3):3-8.

[2] Shi H N.Campus culture[M].Beijing Medical University Union Press, 1993,12,11-13.

[3] Li S D, Hui M.Sports competition[M].Beijing Sport University Press, 2005,7,19-25.

[4] Li L.Investigation and Research on campus sports culture in colleges and universities of Anhui Province[D].Jiangsu: Huaibei normal university,2012.

[5] Zhang K, Li L.Present situation and development countermeasures of organization and management of extracurricular sports competitions in colleges and universities[J].Journal of Guangzhou University, 2010,9(7):74-77.

[6] Liu D.Research on interaction between university sports competition and campus culture construction[D].Jiangsu: Soochow University, 2007. 